\title{
Calcination/Dissolution Residue Treatment
}

\author{
R. C. Knight \\ R. F. Creed
}

Westinghouse Hanford Company

G. K. Patello

G. W. Hollenberg

M. F. Buehler

S. M. O'Rouke

Battelle, Pacific Northwest Laboratories

A. Visnapuu

U.S. Bureau of Mines, Rolla, Missouri

D. F. McLaughlin

Westinghouse Science and Technology Center, Pittsburgh, Pennsylvania

Date Published

September 1994

Prepared for the U.S. Department of Energy

Office of Environmental Restoration and

Waste Management

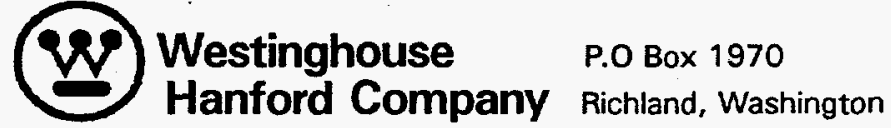

Hanford Operations and Engineering Contractor for the

U.S. Department of Energy under Contract DE-AC06-87RL10930 


\section{DISCLAIMER}

This report was prepared as an account of work sponsored by an agency of the United States Government. Neither the United States Government nor any agency thereof, nor any of their employees, make any warranty, express or implied, or assumes any legal liability or responsibility for the accuracy, completeness, or usefulness of any information, apparatus, product, or process disclosed, or represents that its use would not infringe privately owned rights. Reference herein to any specific commercial product, process, or service by trade name, trademark, manufacturer, or otherwise does not necessarily constitute or imply its endorsement, recommendation, or favoring by the United States Government or any agency thereof. The views and opinions of authors expressed herein do not necessarily state or reflect those of the United States Government or any agency thereof. 


\section{DISCLAIMER}

Portions of this document may be illegible in electronic image products. Images are produced from the best available original document. 


\section{RELEASE AUTHORIZATION}

Document Number: WHC-EP-0818

Document Title: Calcination/Dissolution Residue Treatment

Release Date: $\quad 9 / 23 / 94$

This document was reviewed following the procedures described in WHC-CM-3-4 and is:

APPROVED FOR PUBLIC RELEASE

*************

WHC Information Release Administration Specialist:

Christine Hellénglemon

C. Willingham

$9 / 23 / 94$

(Signature)

(Date) 


\section{CALCINATION/DISSOLUTION RESIDUE TREATMENT}

R. C. Knight

R. F. Creed

G. K. Patello

G. W. Hollenberg

M. F. Buehler

S. M. O'Rourke

A. Visnapuu

D. F. McLaughl in

\section{ABSTRACT}

Currently, high-level wastes are stored underground in steel-7ined tanks at the U.S. Department of Energy's Hanford Site. Current plans call for the chemical pretreatment of these wastes before their immobilization in stable glass waste forms. One candidate pretreatment approach, calcination/dissolution, performs an alkaline fusion of the waste and creates a high-level/low-level partition based on the aqueous solubilities of the components of the product calcine. Further treatment of the high-level insoluble residue remaining following calcination/dissolution would enhance the separation and reduce the quantity of waste consigned to the high-level fraction.

Literature and laboratory studies were conducted with the goal of finding a residue treatment technology that would decrease the quantity of high-level waste glass required following calcination/dissolution waste processing. Four elements (i.e., iron, nickel, bismuth, and uranium) postulated to be present in the high-level residue fraction were identified as being key to the quantity of high-level glass formed. Literature studies revealed several candidate technologies that could be applied to removing iron, nickel, and 
bismuth. Uranium removal approaches, accomplished with nuclear industry technologies, were not applicable to removal of any of the other key elements. Laboratory tests of the candidate technologies with simulant high-level residues showed reductive roasting followed by carbonyl volatilization to be successful in removing iron, nickel, and bismuth. Subsequent bench-scale tests on residues from calcination/dissolution processing of genuine Hanford Site tank waste showed iron was separated with radioelement decontamination factors of 70 to 1,000 times with respect to total alpha activity. Decontamination factors of about 6 to 200 were achieved for Strontium-90, the radionuclide present in highest concentration in the residue.

Thermodynamic analyses of the calcination of five typical Hanford Site tank waste compositions also were performed. The analyses showed sodium hydroxide to be the sole molten component in the waste calcine and emphasized the requirement for waste blending if fluid calcines are to be achieved. Other calcine phases identified in the thermodynamic analysis indicate the significant thermal reconstitution accomplished in calcination. 


\section{CONTENTS}

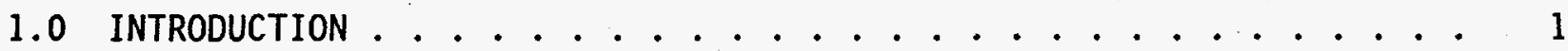

2.0 TECHNICAL TASK PLAN OBJECTIVES ................ 2

2.1 CHARACTERIZATION .................... 2

2.2 SEPARATIONS DEVELOPMENT . . . . . . . . . . . 3

3.0 SELECTION OF WASTE TYPES . . . . . . . . . . . . 3

4.0 RESIDUE SEPARATIONS DEVELOPMENT ................ 5

4.1 LITERATURE REVIEW . . . . . . . . . . . . . . . . 5

4.2 SEPARATIONS TESTING ................... 7

4.2.1 Magnetic Separation and Acid Leaching ....... 7

4.2.2 Carbonylation ............... 7

4.2.3 Electrodeposition ............. 8

4.2.4 Recommended Process for Radioactive Testing . . . . . 9

4.3 CARBONYL PROCESSING OF CALCINATION/DISSOLUTION RESIDUE FROM

GENUINE WASTE . . . . . . . . . . 9

4.4 THERMODYNAMIC SIMULATION OF OXIDATIVE CALCINATION OF HANFORD

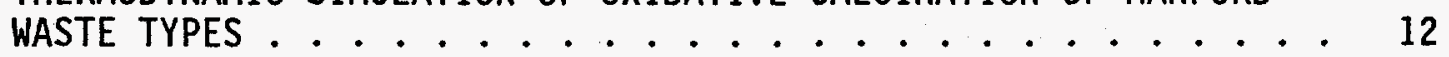

5.0 CONCEPTUAL CALCINATION/DISSOLUTION/RESIDUE TREATMENT FLOWSHEET . . 13

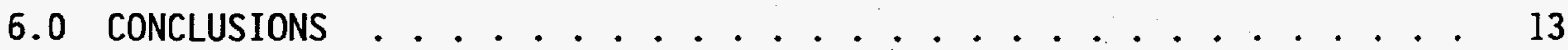

7.0 REFERENCES ................... 16 
WHC-EP-0818

LIST OF FIGURES

1 Calcination/Dissolution/Residue Treatment Conceptual Flowsheet . . . 14

\section{LIST OF TABLES}

1 Composition of Stimulant Residue . . . . . . . . . . . . 5

2 Relative Decreases of Iron, Nickel, and Bismuth in Simulant Residue by Reductive Roasting and Carbonylation . . . . . . . . . . 8

3 Comparison of Residue Treatment Technologies . . . . . . . . . . . 9

4 Composition of Tank 104-T Residue . . . . . . . . . . . . . . 10

5 Radionuclide Decontamination Factors for Iron in Carbonylation of Tank 104-T Calcination/Dissolution Residue ............. 


\section{LIST OF TERMS}

BPW

$\mathrm{CCW}$

C/D

ESPIP

FY

HCC

HWVP

NSC

PFP

PNL

RPS

TPP

TRU

WHC

WSTC

wt\%
Bismuth Phosphate Process Waste

Complexant Concentrate Waste

Calcination/Dissolution

Efficient Separations and Processing Integrated Program fiscal year

Composite Hanford Tank Waste

Hanford Waste Vitrification Plant

Sodium Nitrate Salt Cake

Plutonium Finishing Plant Waste

Pacific Northwest Laboratory

REDOX Process Sludge

Technical Task Plan

transuranic

Westinghouse Hanford Company

Westinghouse Science and Technology Center

weight percent 
WHC-EP-0818

This page intentionally left blank. 
WHC-EP-0818

\section{CALCINATION/DISSOLUTION RESIDUE TREATMENT}

\subsection{INTRODUCTION}

Plans exist to segregate high-level Hanford Site tank wastes into two fractions before immobilization for long-term storage. One fraction will contain the bulk of the chemical constituents but little of the radioactivity and the second fraction will contain most of the radioactivity (including the transuranic [TRU] elements) but little of the chemical bulk. Both fractions then will be converted to glass waste forms for long-term stability and storage. The low-activity fraction will be stored onsite in a retrievable form while the high-activity fraction will be cast into canisters and stored in the national high-level nuclear waste repository. To aid in operation of the separate low-level and high-level glass melters and to optimize the envisioned high-level/low-level partition, efficient waste pretreatment processing is required.

Calcination/dissolution (C/D) is one method proposed for waste pretreatment. In the $C / D$ process, the retrieved and blended waste first is calcined at about $850^{\circ} \mathrm{C}$. Water dissolution of the product calcine then follows.

Processing by $C / D$ yields a number of benefits. First, calcination converts the copious nitrate and nitrite ions present in the waste to hydroxide ions and benign nitrogen and oxygen offgases. Calcination also converts organic carbon present in the waste to carbonate. The destruction of the nitrate, nitrite, and organic carbon by calcination eliminates foaming as well as NO (oxides of nitrogen) offgas problems at the glass melters. Substantial decrease in waste feed bulk is achieved. Destruction of the organic carbon also removes complexing agents that solubilize strontium and americium in the waste solution and cause the undesired partitioning of these elements to the low-level fraction.

In addition, calcination directs bulk chemical components to the low-level fraction. In the high-hydroxide waste melt produced by calcination, an alkaline fusion takes place that transforms water-insoluble aluminum hydroxide, chromium hydroxide, and phosphate compounds present in the Hanford Site tank waste sludge to water-soluble salts. Because glass formulations can only incorporate low concentrations of aluminum, chromium, and phosphate, solubilizing these components achieves significant reduction in the quantity of high-level glass.

The solution produced in the ensuing water dissolution step will contain sodium salts of hydroxide, aluminate, phosphate, carbonate, and chromate as well as the radioactive cesium and technetium isotopes. Cesium and technetium salts, which already report to the aqueous phase in the existing Hanford Site waste, may be removed by ion exchange or other processes under development and directed to the high-level fraction. The treated solution will comprise the low-level waste fraction. The partially dissolved calcine will leave a residue containing the long-lived TRU elements (primarily plutonium and americium) and radioactive strontium. The residue also will contain 
transition metal hydroxides (e.g., iron, nickel, manganese, and zirconium, but not chromium), sodium aluminosilicates, and alkaline earth phosphates and carbonates (e.g., calcium, strontium). The residue, with any cesium and technetium recovered from solution, will comprise the high-level fraction.

Incentive exists to reduce the quantity of the $C / D$ process residue, thus decreasing the quantity of high-level glass product. Removal of nonradioactive bulk components from the residue would achieve the desired reduction. The Calcine Residue Treatment task addresses this need by application of metallurgical and ceramic processing expertise and technology to residue volume reduction.

The Technical Task Plan (TTP) RL432004 outlined a 2-year program to develop and test methods for treatment of the $C / D$ residue with the goal of reducing the volume and improving the compatibility of the residue for processing into the high-level glass waste form (WHC 1992). Progress in the pursuit of this task achieved in fiscal year (FY) 1993 was reported (Knight 1993). This document summarizes the progress and completion of this task achieved in FY 1994 with reference to the fundamental FY 1993 work. This work was funded by the Office of Technology Development, within the U.S. Department of Energy's Office of Environmental Management, under the Efficient Separations and Processing Integrated Program (ESPIP).

\subsection{TECHNICAL TASK PLAN OBJECTIVES}

The TTP was divided into two subtasks:

- Characterization of the $C / D$ product

- Selection and testing of the residue treatment processes.

\subsection{CHARACTERIZATION}

Characterization included laboratory evaluation of simulated calcined wastes as well as theoretical thermodynamic analyses of the $C / D$ process.

Original plans in the TTP called for the characterization of residue obtained from a calcination process test conducted in November 1992 at the Westinghouse Science and Technology Center (WSTC) using a 1-megawatt plasma torch pilot plant (Gass et a1. 1993). When the residue from that test proved inappropriate for testing as a result of product contamination, an alternative simulant residue was identified, tested, and used for experimentation.

Thermodynamic modelling of the $C / D$ processing of five varied Hanford Site waste compositions was accomplished at the WSTC using a proprietary database in conjunction with a publicly available thermodynamic free energy minimization computer code. The modelling identified chemical products from calcination processing, the composition of the calcine phases (solid or 1iquid) versus temperature, and offgases. 


\subsection{SEPARATIONS DEVELOPMENT}

The focus of this subtask was to identify and test methods for separation of nonradioactive components from the $C / D$ residue. The following criteria were used in process evaluation:

- Product compatibility with Hanford Waste Vitrification Plant (HWVP) glass

- Product compatibility with further treatment

- Maximum total volume reduction

- Minimum process development

- Minimum chemical additions and waste streams

- Process adaptability for remote operations.

A comprehensive review of current mineral processing industry practices and procedures was undertaken. Candidate separations processes were identified and evaluated. Potentially promising technologies then were tested with simulant residue and the optimum residue treatment approach selected. Tests of the optimum residue treatment using C/D residue from genuine tank waste was used to confirm the selected technology.

\subsection{SELECTION OF WASTE TYPES}

The TTP calls for the identification and evaluation of five distinct Hanford Site tank waste compositions. The five waste types were to be used for the thermodynamic evaluations and as models to test the applicability of the calcine residue treatment technology:

- Complexant Concentrate Waste (CCW; modelled on the contents of Tank 241-SY-101 [commonly referred to as Tank 101-SY])

- Bismuth Phosphate Process Waste (BPW)

- REDOX Process STudge (RPS)

- Plutonium Finishing Plant Waste (PFP)

- Sodium Nitrate Salt Cake (NSC)

The Sodium Nitrate Salt Cake, though comprising a large portion of the Hanford tank waste inventory, contains little material that would produce an insoluble residue. Therefore, an alternative waste formulation, chemically representative of the entire Hanford Site tank waste inventory, was selected 
as the fifth waste type. Based on the following considerations, the Composite Hanford Tank Waste (HCC) became the model waste type for experimental testing of the residue treatment:

- The model residue initially specified (the residue generated in the calcination testing of simulated Tank 101-SY waste at WSTC in November 1992) was contaminated with casting sand and refractory. The WSTC product, therefore, was not representative of the residue and was unsuitable for further testing.

- The HCC, representative of the entire Hanford Site tank waste inventory, contains all the constituents of interest for residue separations.

- The HCC more closely represents the blended waste likely required for $C / D$ processing.

An HCC simulant was prepared and subjected to $C / D$ processing to generate the residue required for laboratory testing. The composite contained enhanced quantities of elements (strontium, cerium, zirconium) used as radionuclide surrogates. The behaviors of the TRU elements were modelled by the behaviors of manganese, cerium, and zirconium while the disposition of strontium modelled that of ${ }^{90} \mathrm{Sr}$. However, no adequate nonradioactive surrogate was identified for uranium. Preparation of the residue from $C / D$ processing of the HCC simulant is described by Knight (1993).

The composition of the simulant residue is presented in Table 1 . The composition generally confirms the composition predicted and observed in the $C / D$ processing of genuine Hanford Site tank wastes (i.e., it is high in transition metals, lanthanides, bismuth, the alkaline earths, and may also contain sodium aluminosilicates). Iron clearly dominates the residue on both a mole and a weight basis. 
Table 1. Composition of Stimulant Residue.

\begin{tabular}{|c|c|c|}
\hline \multirow{2}{*}{ Element } & \multicolumn{2}{|c|}{ Concentration } \\
\hline & Weight $(\%)$ & Mole (\%) \\
\hline \multicolumn{3}{|c|}{ Separation Targets } \\
\hline $\mathrm{Fe}$ & 34.0 & 43.9 \\
\hline $\mathrm{Ni}$ & 3.3 & 4.1 \\
\hline $\mathrm{Bi}$ & 11.5 & 4.0 \\
\hline \multicolumn{3}{|c|}{ Surrogates for Radioactive Species } \\
\hline $\mathrm{Sr}$ & 5.2 & 4.3 \\
\hline $\mathrm{Ce}$ & 7.9 & 4.0 \\
\hline $\mathrm{Zr}$ & 5.0 & 3.9 \\
\hline \multicolumn{3}{|c|}{ Other } \\
\hline $\mathrm{Na}$ & 3.2 & 10.0 \\
\hline$K$ & 1.3 & 2.4 \\
\hline AT & 1.6 & 4.1 \\
\hline Si & 2.2 & 5.6 \\
\hline$M n$ & 1.7 & 2.2 \\
\hline $\mathrm{Ca}$ & 3.0 & 5.4 \\
\hline $\bar{P}$ & 2.6 & 6.0 \\
\hline
\end{tabular}

\subsection{RESIDUE SEPARATIONS DEVELOPMENT}

The development and testing of candidate residue processes was conducted by personnel of the Materials Science Department of the Battelle Pacific Northwest Laboratory (PNL). The involvement of the United States Bureau of Mines and Westinghouse Hanford Company (WHC) was added in FY 1994. Work scope included a study of waste vitrification requirements, a comprehensive review of existing separations processes used in the metals, minerals refining and ceramic processing industries, and selection and testing of promising separations technologies.

\subsection{LITERATURE REVIEW}

The elements having the largest impact on HWVP product glass volume present in the insoluble residue were found to be nickel, iron, bismuth, phosphorus, and uranium (Knight 1993). Twelve candidate separations process technologies were identified and evaluated based on their promise in removing 
the five target elements. Conditioning processes also were identified to convert the residue to chemical or physical forms more amenable to processing. The following conditioning and separations processes were considered (Knight 1993):

- Conditioning

- Recalcining--forms oxide powder

- Reductive roasting--forms metal

- Acid dissolution

- Separation

- Electrophoresis--particle zeta potential in solution

- Froth flotation--particle zeta potential on bubbles

- Magnetic separation--magnetic susceptibility and attraction

- Electrostatic--electrical charge on particles

- S7ag/melt--reduction, melting, and coalescence of metals

- Carbonylation--formation of volatile metal carbonyl compounds

- Molten salt extractions--electroreduction of metals from melt

- Leaching--selective acid solubility

- Electrochemical plating--electrodeposition of metals from solution

- Electrodialysis/salt splitting--electrolysis of dissolved salts

- Solvent extraction--extraction of ions into immiscible solvent

- Ion exchange--sorption of ions onto fixed bed of resin.

On the basis of literature and technical evaluations, magnetic separation, acid leaching, electrodeposition, and carbonyl processing were selected for laboratory studies. The solvent extraction and ion exchange processes were not considered further under the present task because of the high level of development activity already focussed upon them in other programs. All four selected processes were believed to be effective for removing iron and nickel. All but carbonyl processing were believed to be effective for bismuth separation. No other single process could address more than three of the target elements.

The remaining two target elements are phosphorus and uranium. Phosphorus was considered to be of secondary importance following laboratory testing of the C/D process with genuine wastes (Delegard et al. 1994). The laboratory work showed that, with sufficient washing, most of the phosphorus (present as phosphate) was dissolved leaving little phosphate in the residue except that associated with alkaline earth elements such as calcium and strontium. Slight uranium dissolution was found to occur in C/D processing. However, only nuclear industry processes (including solvent extraction and ion exchange, but a) so including carbonate leaching) were identified in the technical review that addressed uranium separation. None of the uranium separation processes, however, were applicable to iron, nickel, or bismuth. 
WHC-EP-0818

\subsection{SEPARATIONS TESTING}

The four candidate separations technologies identified in the literature review were tested with the HCC residue. Results of the tests with the magnetic separation and acid leaching processes (each preceded by both no conditioning and by reductive roast conditioning) were reported in FY 1993 (Knight 1993). Results of tests with the carbonyl and electrodeposition processing technologies (preceded by acid dissolution and reductive roast conditioning, respectively) are summarized and compared with the results from the earlier magnetic separation and acid leaching processes.

\subsubsection{Magnetic Separation and Acid Leaching}

Reductive roasting successfully converted the largely amorphous simulant residue (Table 1) into a crystalline agglomerate of metallic iron (from the amorphous iron hydroxide) and possibly metallic nickel. Despite the production of these magnetic phases, however, magnetic separation was unsuccessful because of intimate mixing of the magnetic with the nonmagnetic particles containing radioactive surrogate elements. Magnetic separation also was unsuccessful for the untreated simulant residue because nothing in the residue was magnetic.

Nitric acid leaching of the untreated residue dissolved iron, bismuth, nickel, and strontium. The selective leaching of target elements thus was not successful due to the contamination by strontium. Acid leaching of the reductively roasted simulant residue also was unsuccessful due to corollary leaching of strontium, cerium, and manganese with the iron, bismuth, and nickel.

\subsubsection{Carbonylation}

Carbonylation, known commercially as the Mond carbonylation process in the separation and purification of nickel, separates the targeted iron and nickel by way of volatilization of the respective metal carbonyls $\left[\mathrm{Fe}(\mathrm{CO})_{5}\right.$ and $\left.\mathrm{Ni}(\mathrm{CO})_{4}\right]$. In the carbonylation process, the initial step is reductive roasting of the residue with hydrogen gas at atmospheric pressure and temperatures ranging from 650 to $1000{ }^{\circ} \mathrm{C}$. This step reduces iron, nickel, and bismuth to their metallic states. Tests with the simulant residue showed that above $800{ }^{\circ} \mathrm{C}$, bismuth metal volatilizes (the melting point of bismuth is about $270^{\circ} \mathrm{C}$ ) and leaves the chemically reduced residue.

The reductively roasted residue then is treated with a flowing stream of carbon monoxide gas at about $150^{\circ} \mathrm{C}$ and $10 \mathrm{MPa}$ (100 atmospheres). Volatile iron and nickel carbonyls form, exit the reactor chamber with the excess carbon monoxide stream, and are conducted to a decomposition chamber. In the $300{ }^{\circ} \mathrm{C}$ decomposition chamber, the carbonyl compounds are destroyed. The product iron and nickel metals deposit on the walls of the decomposition chamber while the liberated carbon monoxide is conducted out of the decomposition chamber where it may be flamed off or recycled to treat subsequent batches of reductively roasted residue. 
In carbonylation tests of simulant residue reductively roasted at $850{ }^{\circ} \mathrm{C}$, the metal plate recovered from the decomposition chamber was found to be about 85 weight percent (wt\%) iron and 13 wt\% nickel with lesser amounts of sodium, potassium, silicon, bismuth, and other elements. Significantly, the surrogate radioelements (cerium, zirconium, and strontium) in the volatilized and plated material were below analytical detection limits.

The amounts of iron, nickel, and bismuth removed from the simulant residue by reductive roasting and carbonylation processing are presented in Table 2. As shown in Table 2, the segregation of bismuth achieved at higher temperature is offset by a decrease in iron and nickel segregation. The decrease of iron and nickel volatilization is attributed to lowered surface areas of these metals caused by agglomeration at higher temperatures.

Table 2. Relative Decreases of Iron, Nicke1, and Bismuth in Simulant Residue by

Reductive Roasting and Carbonylation.

\begin{tabular}{|c|c|c|c|}
\hline $\begin{array}{c}\text { Roasting } \\
\text { temperature } \\
\left({ }^{\circ} \mathrm{C}\right)\end{array}$ & \multicolumn{3}{|c|}{ Relative decrease (\%) } \\
\cline { 2 - 4 } & Iron & Nicke 7 & Bismuth \\
\hline 650 & 92 & 93 & 0 \\
\hline 850 & 85 & 96 & 90 \\
\hline 1000 & 86 & 70 & 97 \\
\hline
\end{tabular}

Based on the behaviors of iron, nickel, and bismuth, a three-step carbonyl process sequence is proposed:

- Reductive roasting at $650^{\circ} \mathrm{C}$, or lower, to produce iron, nickel, and bismuth metal.

- Carbonyl compound formation and volatilization, at about $150^{\circ} \mathrm{C}$, followed by separate decomposition to metal at $300{ }^{\circ} \mathrm{C}$ to remove iron and nickel.

- Renewed roasting of the iron- and nickel-denuded residue at $850{ }^{\circ} \mathrm{C}$, or higher, to volatilize bismuth.

\subsubsection{Electrodeposition}

Electrodeposition of bismuth, iron, and nickel was tested using both simplified solutions (acid solutions containing only individual metals of interest) and acid solutions of simulant residue. Acids tested to dissolve the simulant residue included 1 molar hydrochloric acid and aqua regia formulations (containing 1 molar concentrations of both nitric and hydrochloric acids). Hydrochloric acid alone dissolved iron and nickel but did not dissolve bismuth. Aqua regia dissolved iron, nickel, and bismuth. 
Electrodeposition successfully plated bismuth from both simplified and acid-dissolved simulant residue. Nickel and iron deposition was more difficult and yielded lower current efficiencies. Current efficiency losses also were attributed to the simultaneous acid dissolution of the electroplate and to the reduction of hydrogen ion and nitrate. Significant contamination of the electroplate by strontium occurred in tests with the simulant residue. The strontium contamination possibly was due to local precipitation of strontium hydroxide at the electrode surface. Because of the strontium contamination, electrodeposition is considered to be unsuitable for calcine residue treatment. The necessity of using corrosive hydrochloric acid media to dissolve the residue is also a considerable drawback to residue processing by electrodeposition.

\subsubsection{Recommended Process for Radioactive Testing}

On the basis of the technology review and the laboratory tests with simulant residue and in light of the selection criteria enumerated in Section 2.2, the carbonyl process was recommended for radioactive testing using $C / D$ residue originating from genuine Hanford tank waste. The relative merits and performance of the four candidate residue treatment technologies identified in tests with the simulant $C / D$ residue are presented in Table 3 .

Table 3. Comparison of Residue Treatment Technologies.

\begin{tabular}{|l|l|c|c|l|}
\hline Technology & \multicolumn{1}{|c|}{ Approach } & $\begin{array}{c}\text { Add to } \\
\text { waste }\end{array}$ & $\begin{array}{l}\text { Elements } \\
\text { targeted }\end{array}$ & Elements separated \\
\hline $\begin{array}{l}\text { Acid } \\
\text { leaching }\end{array}$ & $\begin{array}{l}\text { Selective leaching } \\
\text { by acid. }\end{array}$ & Yes & $\begin{array}{l}\mathrm{Fe}, \mathrm{Ni} \\
\mathrm{Bi}\end{array}$ & $\begin{array}{l}\text { None; leachate } \\
\text { contaminated with } \mathrm{Sr}\end{array}$ \\
\hline $\begin{array}{l}\text { Magnetic } \\
\text { separation }\end{array}$ & $\begin{array}{l}\text { Reduction by } \\
\text { hydrogen; magnetic } \\
\text { removal of metal }\end{array}$ & $\mathrm{No}$ & $\mathrm{Fe}, \mathrm{Ni}$ & $\begin{array}{l}\text { None; particles } \\
\text { adhered compromising } \\
\text { separation }\end{array}$ \\
\hline $\begin{array}{l}\text { Electro- } \\
\text { deposition }\end{array}$ & $\begin{array}{l}\text { Dissolution in } \mathrm{HCl} \\
\text { or aqua regia; } \\
\text { selective } \\
\text { electrodeposition }\end{array}$ & Yes & $\mathrm{Fe}, \mathrm{Ni}$, & $\begin{array}{l}\text { None; Sr } \\
\text { contamination in } \\
\text { electrodeposit }\end{array}$ \\
\hline $\begin{array}{l}\text { Carbonyl } \\
\text { volatili } \\
\text { zation }\end{array}$ & $\begin{array}{l}\text { Reduction by } \\
\text { hydrogen; carbonyl } \\
\text { volatilization } \\
\text { followed by thermal } \\
\text { deposition of metal }\end{array}$ & $\mathrm{No}$ & $\mathrm{Fe}, \mathrm{Ni}$ & $\begin{array}{l}\text { Fe, Ni, Bi. Clean } \\
\text { deposit of Fe and } \mathrm{Ni} . \\
\text { Volatilization and } \\
\text { removal of Bi metal } \\
\text { also occurs. }\end{array}$ \\
\hline
\end{tabular}

\subsection{CARBONYL PROCESSING OF CALCINATION/DISSOLUTION RESIDUE FROM GENUINE WASTE}

Residue from C/D processing of genuine waste from Hanford waste Tank 241-T-104 (commonly referred to as Tank 104-T) was used to test the carbonyl processing technology. The testing was performed with a new apparatus based on designs and conditions established in the tests performed at the U.S. Bureau of Mines. To reduce problems associated with transfer of 
radioactive materials, the reductive roast and the carbonylation steps were performed in the same pressure apparatus without moving the residue materials. To confirm laboratory procedures, preliminary tests were run with the HCC simulant residue.

In tests with the HCC simulant residue and the single chamber reaction vessel, reductive roasting (at $650^{\circ} \mathrm{C}$ ) followed by carbonlyation produced separated deposits rich in iron (about $65 \mathrm{wt} \%$ ) and nickel (about $31 \mathrm{wt} \%$ ) but having undetectable concentrations of the surrogate radioelements (zirconium, cerium, strontium, or manganese). About $75 \%$ of the iron was removed from the simulant HCC residue (compared with $92 \%$ iron removal achieved with the separate reductive roasting and carbonylation chambers in optimized tests at the U.S. Bureau of Mines). About $8 \%$ of the bismuth volatilized under the experimental conditions employed.

The genuine waste taken from Tank 104-T originated from the first decontamination cycle of the Bismuth Phosphate Process (1C waste) and from aluminum cladding removal waste. Because the wastes from Tank 104-T contained components difficult to dissolve by direct C/D processing, sodium nitrate was blended with the Tank 104-T waste before calcination. Addition of the reagent sodium nitrate simulated blending with Hanford Site tank waste salt cake, which was not available for these tests, and served to provide additional fluxing agent from the sodium hydroxide produced by sodium nitrate decomposition. Hanford Site salt cakes have been shown to be predominantly sodium nitrate. The composition of the $C / D$ residue produced from Tank 104-T waste is shown in Table 4 .

Table 4. Composition of Tank 104-T Residue.

\begin{tabular}{|c|c|c|}
\hline \multirow{2}{*}{ Element } & \multicolumn{2}{|c|}{ Concentration (\%) } \\
\cline { 2 - 3 } & Weight & Mole \\
\hline $\mathrm{Fe}$ & 11.7 & 19.3 \\
\hline $\mathrm{Bi}$ & 11.6 & 5.1 \\
\hline $\mathrm{Na}$ & 7.7 & 30.9 \\
\hline $\mathrm{Al}$ & 5.9 & 20.3 \\
\hline $\mathrm{Si}$ & 5.9 & 19.5 \\
\hline $\mathrm{Mn}$ & 0.2 & 0.4 \\
\hline $\mathrm{Zr}$ & 0.2 & 0.2 \\
\hline $\mathrm{Ca}$ & 0.2 & 0.5 \\
\hline $\mathrm{Sr}$ & 0.1 & 0.1 \\
\hline $\mathrm{P}$ & 1.2 & 3.4 \\
\hline $\mathrm{U}$ & 0.7 & 0.3 \\
\hline
\end{tabular}


The Tank 104-T C/D residue contains more sodium, aluminum, and silicon, about the same amount of bismuth, and less iron than the HCC residue described in Table 1. Nickel could not be determined reliably for the Tank 104-T C/D residue because analyses used nickel crucibles.

Residue from the $C / D$ processing of Tank 104-T sludge then was subjected to reductive roasting and carbonylation under essentially identical conditions to those employed with the HCC residue. In duplicate experiments, iron separation was found to be less extensive than that shown in the simulant tests. Analyses of the initial residue, the residue following carbonylation, and the separated iron-rich deposit showed that only about 16 to $19 \%$ of the iron was removed from the $C / D$ residue. About 14 to $17 \%$ of the bismuth also was separated by direct metal volatilization. The separated iron underwent decontamination from the radioactive species present in the HLW residue (Table 5).

Table 5. Radionuclide Decontamination Factors for Iron in Carbonylation of Tank 104-T Calcination/Dissolution Residue.

\begin{tabular}{|c|c|c|}
\hline \multirow{2}{*}{ Radionuclide } & \multicolumn{2}{|c|}{ Decontamination factor } \\
\cline { 2 - 3 } & Run 1 & Run 2 \\
\hline${ }^{90} \mathrm{Sr}$ & 6 & 200 \\
\hline${ }^{137} \mathrm{Cs}$ & $>0.1$ & $>0.4$ \\
\hline${ }^{239}{ }^{240} \mathrm{Pu}$ & $>8$ & $>10$ \\
\hline${ }^{241} \mathrm{Am}$ & $>0.2$ & $>0.5$ \\
\hline Total alpha & 70 & 1,000 \\
\hline Total beta & 0.8 & 2 \\
\hline
\end{tabular}

As shown in Table 5, cesium, plutonium, and americium were not detectible in the iron-rich materials separated from the $C / D$ residue. Depending on the detection level reached, the decontamination factors for these species were greater than about 0.1 to 10 . Trace ${ }^{90} \mathrm{Sr}$ was detected in the separated iron. Decontamination factors calculated for ${ }^{90} \mathrm{Sr}$ ranged from 6 to 200 . Total alpha activity decontamination factors ranged from 70 to 1,000 , while total beta activity decontamination factors were 0.8 to 2 .

Crystalline (X-ray diffraction) analyses of the material remaining following carbonylation treatment found bismuth metal and the sodium aluminosilicate nepheline. Bismuth metal was produced by reductive roasting. Nepheline is known to be formed by heating of hydrothermally formed sodium aluminosilicates such as cancrinite. The low amount of iron removed from the residue is attributed to the relatively large quantity of bismuth present in the hydrogen-reduced residue. The molten bismuth metal produced in the $650^{\circ} \mathrm{C}$ reductive roast is thought have occluded the iron and thus decreased the access of the carbon monoxide to the iron in the subsequent carbonylation step. 
WHC-EP-0818

\subsection{THERMODYNAMIC SIMULATION OF OXIDATIVE CALCINATION OF HANFORD WASTE TYPES}

Detailed thermodynamic calculations were performed to determine the chemical and physical behavior of the five selected Hanford tank waste compositions to calcination processing. The five waste types selected (Section 3.0) were Complexant Concentrate Waste (CCW), Bismuth Phosphate Process Waste (BPW), REDOX Process Sludge (RPS), PFP Waste (PFP), and Composite Hanford Tank Waste (HCC). Thermodynamically preferred species of 40 elements resulting from calcination were identified, the volatilization losses and offgas products predicted, and the solid-liquid phase partitioning described. The complete results of the thermodynamic modelling were presented by McLaugh 7 in and Peterson (1993).

The thermodynamic analyses predicted that the only liquid phase existing in the heated calcine would be sodium hydroxide (melting point $312{ }^{\circ} \mathrm{C}$ ). Other compounds formed would either be dissolved in the molten sodium hydroxide (e.g., sodium carbonate) or would form separate insoluble solid phases (e.g., sodium aluminate). The key to obtaining a fluid melt was the presence of sufficient sodium hydroxide (or sodium hydroxide-forming phases such as sodium nitrate and nitrite) in the calcine feed. Because sodium hydroxide was found to be the sole molten component in the calcine, alternative calcination processing strategies were proposed:

- Develop separate calcination systems for high and low sodium hydroxide wastes. Use "dry" or powder calcining techniques for the low sodium hydroxide materials (e.g., BPW and RPS) and fluid slagging calcining approaches for high sodium hydroxide materials (e.g., CCW).

- Blend the low sodium hydroxide wastes with sodium nitrate salt cake. Blending of existing Hanford tank wastes in the proper proportions can convert all feed streams to compositions that will form fluid slags upon calcination.

The thermodynamic analysis made other predictions important for the design and operation of a calcination process:

- As anticipated and observed in earlier WSTC pilot calciner demonstration tests, nitrate and nitrite will decompose thermally to give nitrogen and oxygen offgases with only small concentrations of $\mathrm{NO}_{\mathrm{x}}$.

- If calcination product collection will be in a crucible, the crucible temperature must be maintained at temperatures below $800{ }^{\circ} \mathrm{C}$ to reduce "dry out" of the slag due to evaporation of the molten sodium hydroxide solvent. Similarly, heat transfer gas flow should be minimized to reduce stripping of the volatile sodium hydroxide.

- For waste calcines having no free sodium hydroxide, the carbon dioxide liberated by calcination of organic carbon will escape to the offgas; for calcines with free sodium hydroxide, the carbon dioxide will be scrubbed and captured as carbonate. Carbon monoxide 
production will be negligible. Carbon dioxide in the feed gas also will be scrubbed by calcines containing free sodium hydroxide to form sodium carbonate.

- Chemical reactivity sequences in the calcination were elucidated. Phosphate will preferentially react with alkaline earths (calcium, strontium), then with aluminum. Aluminum will react first with phosphate, then with sodium. Iron will react first with sodium, then form ferric oxide. Sodium will preferentially react with aluminum, iron, chromium, and carbonate before forming sodium hydroxide.

\subsection{CONCEPTUAL CALCINATION/DISSOLUTION/RESIDUE TREATMENT FLOWSHEET}

Based on the results of the $C / D$ process development work and the residue treatment studies reported here, a conceptual Calcination/Dissolution/Residue Treatment flowsheet may be proposed (Figure 1). The flowsheet incorporates the carbonyl process to achieve the removal of iron, nickel, and bismuth from the C/D residue through the volatilization of the iron and nickel carbonyls and subsequent evaporation of bismuth metal.

As outlined in Figure 1 , the heel remaining after the carbonyl process will contain only sodium aluminosilicates (such as nepheline), the alkaline earth phosphates, and zirconium, manganese, and rare earth oxides as the bulk chemical components. The heel also will contain the radioactive TRU elements, thorium, most of the uranium, and radioactive isotopes of strontium and the rare earths. Under the proposed flowsheet, the heel will be consigned to the HLW fraction for processing into glass. Cesium and possibly technetium will al so be sent to the HLW following removal from the $C / D$ product solution.

\subsection{CONCLUSIONS}

The Calcine Residue Treatment task was conducted during FYs 1993 and 1994 to identify and test candidate technologies for minimizing the quantity of residue remaining for $H L W$ vitrification following $C / D$ treatment of Hanford Site tank waste. The steps taken to accomplish this task and the results of the investigation are summarized.

- Identified elements expected to be present in the $C / D$ residue and key contributors to HLW glass volume. The key elements initially identified were iron, nickel, bismuth, phosphorus, and uranium. Because related investigations showed C/D processing successfully removed phosphorus from the HLW fraction, no further inquiry into phosphorus separation was undertaken. 


\section{CALCINATION/DISSOLUTION/RESIDUE TREATMENT}

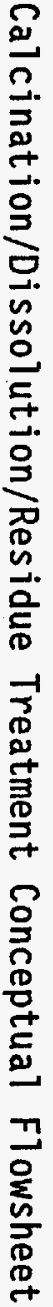

Scrub offgas; refurn $\mathrm{H} 2 \mathrm{O}$ for retrieval; discharge

N2 and 02 gases.

Feed Waste Calcination

Blended retrieved waste

slurries from Tank Farms

calcined @850C. Nitrate,

nitrile, organics decompose.

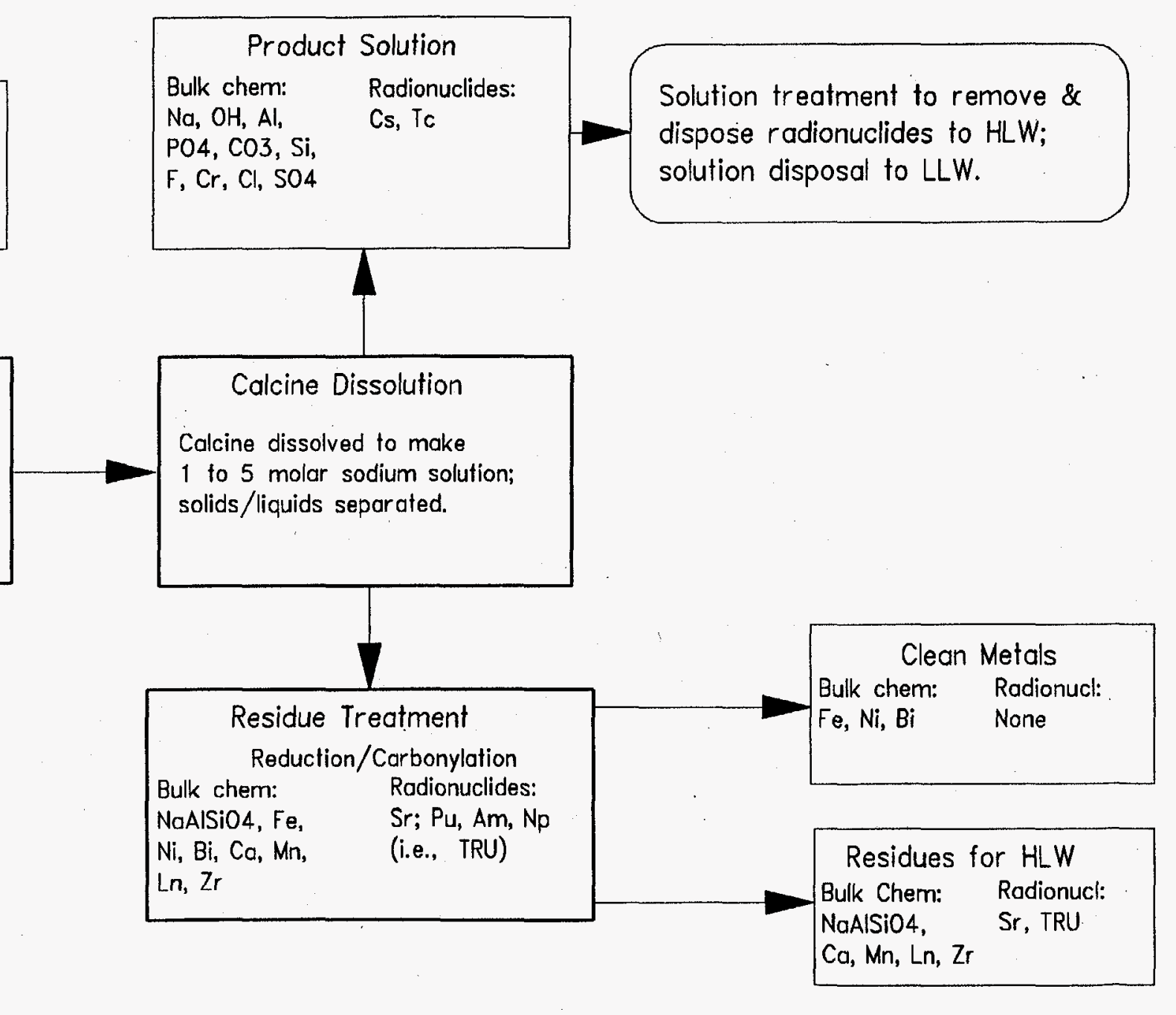


- Surveyed existing technologies employed in the metallurgical and ceramic processing industries for their applicability to remove the remaining key elements (iron, nickel, bismuth, and uranium) from the $C / D$ residue. Three residue conditioning processes and tweive separation processes were identified. Of these, two conditioning processes (reductive roasting and acid dissolution) and four separation processes (acid leaching, magnetic extraction, electrodeposition, and carbonyl volatilization) were selected for laboratory investigations with simulant C/D residue. These processes were judged applicable to iron, nickel, and possibly bismuth separation. For uranium, only Hanford-proven nuclear industry processes (solvent extraction and ion exchange) were expected to be successful. The nuclear industry processes applicable to uranium were not expected to be useful for segregation of any of the other key elements.

- Tested promising technologies on simulant $C / D$ residue. of the four separation processes tested, only carbonyl processing (preceded by reductive-roast conditioning) cleanly separated the target metals from radioelement surrogates. Carbonyl processing separated 85 to 92\% of the iron and 70 to $96 \%$ of the nickel from the C/D residue; up to $97 \%$ bismuth removal by direct metal volatilization al so was achieved. Contamination of the separated elements by radioelement surrogates was not detectible.

- Confirmed the performance of the best technology (reductive roasting followed by carbonyl processing) using residue from C/D processing of a genuine Hanford Site tank waste. As a result of suspected mixing with abundant bismuth metal, carbonyl processing of $C / D$ residue from Tank 104-T sludge separated only about $17 \%$ of the available iron. Decontamination factors of about 6 to 200 were achieved for ${ }^{90} \mathrm{Sr}$, the radionuclide found in highest concentration in the residue. Total alpha activity decontamination factors ranged from 70 to 1,000 .

- Investigated the thermodynamics of the calcination process as applied to five varied Hanford waste types. The thermodynamic analysis confirmed the expected destruction of nitrate and nitrite to form benign nitrogen and oxygen offgases and indicated sodium hydroxide to be the only component molten at the target 650 to $850{ }^{\circ} \mathrm{C}$ calcine temperature. Blending of certain waste types with sodium nitrate salt cake will be required to maintain molten calcine product. Operation at lower calcine temperatures and heat transfer gas rates will be necessary to prevent slag "dry out" resulting from evaporative loss of sodium hydroxide solvent. 


\subsection{REFERENCES}

Delegard, C. H., T. D. Elcan, and B. E. Hey, 1994, Chemistry of the Application of Calcination/Dissolution to the Hanford Tank Waste Inventory, WHC-EP-0766, Westinghouse Hanford Company, Richland, Washington.

Gass, W. R., S. V. Dighe, and D. F. McLaughl in, 1993, Plasma Calcination of Simulated High-Level Nuclear Waste, 93-9TD3-CALCI-R1 (Revision 1), Westinghouse Science and Technology Center, Pittsburgh, Pennsylvania.

Knight, R. C., 1993, Calcine Residue Treatment Summary Report, WHC-SD-WM-PE-052, Rev. 0, Westinghouse Hanford Company, Rich 1 and, Washington.

McLaughlin, D. F., and S. H. Peterson, 1993, Thermodynamic Simulation of Oxidative Plasma Calcination of Five Hanford High-Level Tank Waste Compositions, 94-9TD2-CALMO-RI, Westinghouse Science and Technology Center, Pittsburgh, Pennsylvania.

WHC, 1992, Calcine Residue Leaching: Volume Reduction for High-Level Waste S7udges, TTP RL432004, Westinghouse Hanford Company, Richland, Washington. 
WHC-EP-0818

DISTRIBUTION

Number of Copies

OFFSITE

1

U. S. Bureau of Mines

1300 N. Bishop Avenue

P. 0. Box 280

Rolla, MO 65401

Technical Library

3

U. S. Bureau of Mines

729 Arapeen Drive

Salt Lake City, UT 84108-1283

A. Visnapuu

3

U. S. Department of Energy

12800 Middlebrook Road

Trevion II Building

Germantown, MD 20874

T. Fryberger

3

Westinghouse Science and Technology Center 1310 Beulah Road

Pittsburgh, PA 15235-5098

D. F. McLaughl in

ONSITE

13

Battelle, Pacific Northwest Laboratories

M. F. Buehler (3)

G. W. Hollenberg (3)

P8-38

W. L. Kuhn

P7 -20

PNL Technical Files

$\mathrm{K} 2-21$

Hanford Technical Library

G. K. Patello (3)

K. D. Wiemers

$\mathrm{K} 1-11$

P8-55

P7-18

P7-14

MACTEC

D. J. Swanberg

K8-50 
WHC-EP-0818

\section{DISTRIBUTION (continued)}

4

U. S. Department of Energy Richland Operations Office

J. E. Kinzer $\$ 7-50$

B. A. Mauss

K8-50

D. E. Trader

K8-50

Public Reading Room

A1-65

17

\section{Westinghouse Hanford Company}
R. A. Bechtold (3)
J. D. Berger
R. F. Creed (3)
G. E. Culley
C. H. Delegard
D. W. Edmonson
G. B. Griffin
J. R. Jewett
R. C. Knight
B. G. Lauzon
Central Files
OSTI (2)

L0-18

LO-18

N1-21

R3-86

T6-09

T6-09

T6-16

T6-09

L6-38

R1-08

L8-04

L8-15 